\title{
My Life in Names: \\ A Personal Reminiscence
}

\author{
Thomas J. Gasque \\ University of South Dakota
}

My first realization that people actually study names and their origins came from the librarian in my home town of Marion, South Carolina, who showed me an annual periodical called Names in South Carolina (NISC). The one name that I remember is "Wongway Creek," and the article suggested that the name was a misspelling of "wrongway," since the stream flowed in a direction opposite to other nearby creeks. Although my memory of this name is sharp, a recent search failed to turn up evidence of any such case.

Maps have fascinated me from early childhood, and I even thought at one time of becoming a civil engineer so that I could spend my life making maps. But languages also fascinated me, and when I realized that the study of names brought together both of these interests I was hooked, but my obsession lay dormant for several years.

In 1967 I found a little book called The Rhyme of the Southern Rivers, a collection of doggerel verse incorporating the names of the rivers of the American South, by a certain Martin Van Buren Moore. The verses were less interesting than the etymological notes, in which Moore, with great confidence and ingenuity but with little knowledge, derived the names of all of the rivers in America from the names of the four rivers that, according to Genesis 2: 10-14, flow out of the Garden of Eden. I wrote to Claude Henry Neuffer at the University of South Carolina, who with his wife Irene had been publishing the NISC since 1953, proposing an article that discussed those name origins for the rivers in South Carolina. Professor Neuffer was not only encouraging, he was enthusiastic, and my first onomastic article appeared in NISC in 1968. While the Neuffers were life members of the American Name Society and well known among the membership, they did not often attend meetings or take an active part in ANS.

Names 49.4 (December 2001):300-303

ISSN:0027-7738

(C) 2001 by The American Name Society 
That same year I took a position at the University of South Dakota, where Edward Ehrensperger had taught English literature and chaired the English Department for over 30 years. Although he had retired from USD when I arrived, he was still in the area, teaching at Yankton College, about twenty-five miles away, and he frequently visited our campus. Most ANS members know that Ed Ehrensperger annually circulated a summary of research and other activity in name study, and the annual summary now bears the name The Ehrensperger Report in his honor. He was also one of the founders, in 1951, of the American Name Society. He was, in fact, president of ANS in 1968, the year I arrived at USD, and although he knew of my interest in names unfortunately did not prevail on me to join the society at that time. In fact, consumed by teaching and administrative responsibilities, it was a number of years before I actually became a member.

Ed Ehrensperger was the editor of South Dakota Place Names, a WPA publication brought to a hasty conclusion in 1941 by the approaching war. He always realized that that work, which, as a government publication, was not copyrighted, had many serious flaws, and when he took a second retirement from Yankton College he set out to revise it. But in 1973, a reprint bearing the title South Dakota Geographic Names appeared without its editor bothering to inform him, and none of the errors of the original had been corrected. While this book focused attention on place names, Ed realized that the market for any revision he might make was spoiled for the next decade or so.

In the early 1980s, Ed realized that he would not be able to finish the work that he had started, and he asked me to take it on, which I did with some reluctance but with much hope that the job could be done in two or three years. I'm still at it.

It was at about this time that I finally joined the American Name Society. It occurred to me that it would be appropriate for the Society to honor Ed Ehrensperger with a special issue of Names. I wrote to the editor, Kelsie Harder, with that suggestion and learned that he had already given it some thought and had approached Larry Seits as a possible guest editor. Larry called me and suggested that I take over the task. With no editorial experience, I nevertheless agreed and began soliciting essays for inclusion in the Ehrensperger Festschrift. Unfortunately, before the issue appeared, Ed Ehrensperger died at the age of 88, and Names 33: 1-2 (March-April 1985) became a memorial issue. 


\section{Names 49.4 (December 2001)}

I started attending ANS meetings in the early 1980s, shortly after Ed's health prevented him from participating actively as he had done for so many years. Because of my connection to him I got to know most of the members who were active at that time: Bill Nicolaison, Lurline Coltharp, Len Ashley, Fred Cassidy, Fred Tarpley, Kelsie Harder, Grace Alvarez, John Algeo, Alan Rayburn, Sally Jackson, Len Ashley, and Mary Rita Miller, just to name a few of those who served a term as president. I treasured and still treasure these friendships and so many others.

My experience with the special issue for Professor Ehrensperger made me realize that editing can be fun, especially when the contributors included such onomastic worthies as Marvin Carmony, Virgil Vogel, James B. McMillan, and Hamill Kenny, in addition to Read, Nicolaisen, Cassidy, Tarpley, and Algeo. When I learned that Kelsie Harder was thinking of retiring from the editorship, I asked him whether he thought I could handle the job, and the first thing I knew he had handed it over to me, with, I think, the approval of the Executive Council, and I became the editor of Names sooner than I expected.

My first year as editor was complicated by an abundance of riches in my professional life. I was awarded a Fulbright research and teaching fellowship at Oldenburg University in Germany and ended up being away from the United States for well over a year. My first issue, a double one (36.1-2), was completed before leaving, but my second one, a festschrift for Allen Walker Read, had to be done with the assistance of a graduate student and that awkward communication system, which many of you remember, called BITNET. While that number, another double issue (36.3-4), featured some excellent essays and was a fitting tribute for the legendary Read, I was mortified by the many typographical errors that crept in between my editing and the final typesetting.

In the years since my editorship, I have been involved with names in a variety of ways, including two years handling The Ehrensperger Report, the annual review of onomastic research which got its start with its namesake, Ed Ehrensperger. For the last two years I served as vice president of ANS and this year, 2001, I am in the first of my two-year term as president. Meanwhile, my work goes on with the study of the place names of South Dakota, and I have added an interest in the names used and given by the Lewis and Clark expedition of 1804-06. 
In my time with ANS, and my years are not so many compared to others, I have seen many problems: limited financial resources; a membership which is too small for the goals of the Society and which, despite a dedicated core, turns over rapidly from year to year; reluctance on the part of college and university administrations to recognize onomastics as a legitimate discipline; uncertainty of the mission of ANS and its responsibility to people of varying concerns and interests (place names, personal names, names in literature); the inconvenience, for most people, of meeting with the Modern Language Association during the week following Christmas; and many more. Most of these concerns have been addressed in one way or another and will, I hope, continue to be addressed.

The American Name Society is a crucial organization for those of us interested in the fascinating study of names. Surprisingly, the number of people who are interested in this topic is much greater than the membership in ANS reveals. We, as officers and members, need to encourage more active participation by scholars young and old, by students, and by those people outside of the normal academic circles whose interest in names has led to some of the best research and scholarship in the field. The Ehrensperger Report reminds us annually of the work that members throughout the world are doing; The Placename Survey of the United States continues to encourage researchers in every state to find out and publish information about the origins of names. ANS needs to encourage similar cooperative efforts for those interested in other kinds of names-personal names, literary names, and brand and corporate names. Above all, the Society must hold to and continue to insist on the high standards of research and scholarship exemplified by Names: A Journal of Onomastics so that the discipline can take its place in the company of other learned disciplines of this country and the rest of the world.

As a professor of English, my teaching has been mostly in medieval literature, but my research has mostly run in a direction counter to that of most of my colleagues. My decision nearly twenty years ago to focus a large part of my research time on names has greatly enriched my life, both professionally and personally. The friendships, the travel, and the bringing together of my lifetime fascination with the verbal language of names and the graphic language of maps have turned out to be for me the right way, not the wrong way, no matter how you spell it. 